\title{
Acquired haemophilia presenting with tongue swelling and dysphagia
}

\author{
Oliver McLaren, Alexander Walkden
}

Otolaryngology, Head and Neck Surgery, Royal Cornwall Hospitals NHS Trust, Truro, UK

Correspondence to Mr Oliver McLaren, oliver.mclaren@nhs.net

Accepted 15 November 2018

\section{DESCRIPTION}

A 78-year-old woman presented to the emergency department with rapid swelling and bruising of the tongue and anterior neck over a 12 hours period. Other symptoms included dysphagia, dysphonia and tightness in her neck. There was no stridor or clinical evidence of airway compromise. She did not report any trauma or other injuries that could account for the swelling. She had recently suffered an upper respiratory tract infection. Her medical history included osteoarthritis, hypertension and gastro-oesophageal reflux disease. Her medication history consisted of candesartan, simvastatin, omeprazole and simple analgesia as required.

Examination of the patient revealed an obviously discoloured swollen tongue (figure 1), with oedema to the floor of the mouth displacing the tongue superiorly. There was also diffuse ecchymosis of the anterior neck. There were no signs of airway compromise and the patient had full pain-free range of neck movement.

Flexible nasendoscopy was performed to assess airway patency. This showed a patent airway with symmetrical cord movement, and there was some postcricoid oedema suggestive of venous congestion (figure 2) and no evidence of deep neck space collection or haematoma.

On initial laboratory investigations, haemoglobin and platelet counts were normal. Her initial activated partial thromboplastin time (APTT) was elevated at $64.6 \mathrm{~s}$ (reference range 25-35 s), as was her APTT ratio at 2.2. Her factor VIII (FVIII) assay was very low at $4.2 \mathrm{iu} / \mathrm{dL}$ (reference $50-150 \mathrm{iu} / \mathrm{dL}$ ).

The low FVIII levels and raised APTT suggested a diagnosis of acquired haemophilia A.

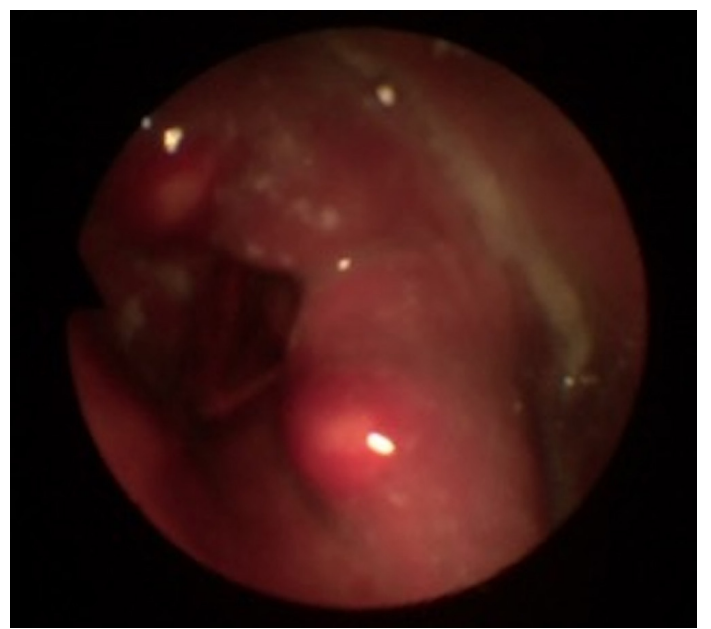

Figure 1 Tongue swelling.

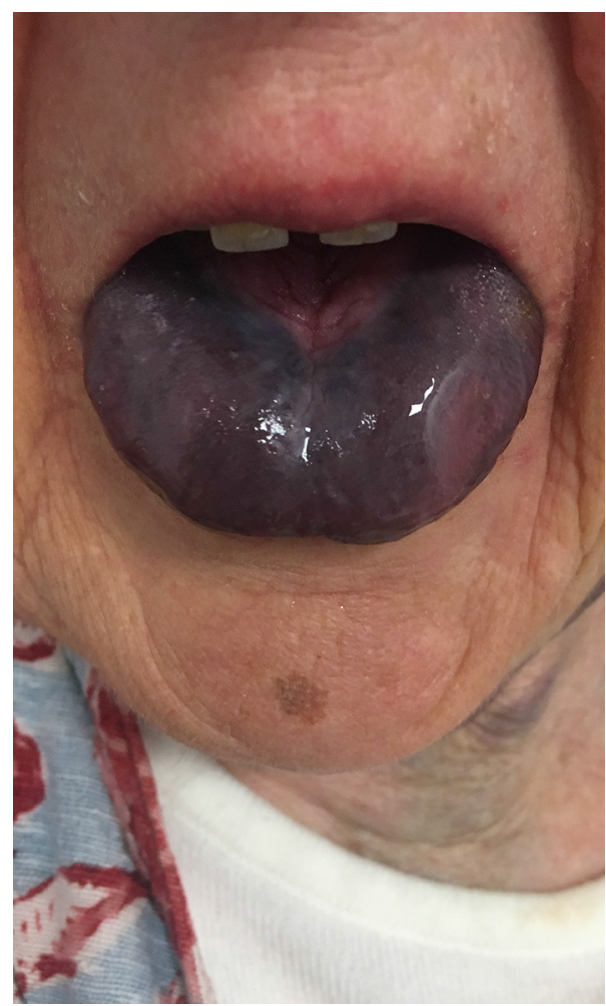

Figure 2 Appearance of larynx with postcricoid oedema.

Acquired haemophilia A is a medical emergency causing potentially life-threatening bleeding due to an autoimmune process. ${ }^{1}$ The body produces autoantibodies, known as FVIII inhibitor, which inhibit the procoagulant activity of FVIII. In approximately $50 \%$ of acquired haemophilia A cases, there is no cause identified, and the remaining 50\% is made up of autoimmune conditions, malignancy, pregnancy and the postpartum period, dermatological conditions and rarely drug reactions. ${ }^{2}$

This patient was treated with factor eight inhibitor bypass activity (FEIBA) intravenously followed by prednisolone and cyclophosphamide. In 30\% of cases, prednisolone alone can induce elimination of FVIII inhibitor and the addition of cyclophosphamide raises this up to $70 \%$. Following administration of FEIBA, her FVIII inhibitor levels fell from 32.6 Bethesda units (BU) to 4 BU. After several days of prednisolone and cyclophosphamide, her FVIII inhibitor test was negative, her APTT returned to within normal limits and her APTT ratio returned to 0.9 . Her FVIII levels rose from $4.2 \mathrm{iu} / \mathrm{dL}$ pretreatment to $162 \mathrm{iu} / \mathrm{dL}$. 


\section{Learning points}

Acquired haemophilia $A$ is a medical emergency with potentially fatal consequences secondary to uncontrollable bleeding. Rapid treatment of acquired haemophilia with bypassing agents prevents further deterioration with.

- Early immunosuppressive treatment with corticosteroids required to eradicate existing autoantibodies and return coagulation status to normal.

- Surgical specialties covering the affected areas should review patients to assess for local complications associated with bleeding.
Contributors OML: primary author. AW: review of article.

Funding The authors have not declared a specific grant for this research from any funding agency in the public, commercial or not-for-profit sectors.

Competing interests None declared.

Patient consent Obtained.

Provenance and peer review Not commissioned; externally peer reviewed.

\section{REFERENCES}

1 Collins P, Macartney N, Davies R, et al. A population based, unselected, consecutive cohort of patients with acquired haemophilia A. Br J Haematol 2004;124:86-90.

2 Baudo F, Collins P, Huth-Kühne A, et al. Management of bleeding in acquired hemophilia a: results from the European Acquired Haemophilia (EACH2) Registry. Blood 2012;120:39-46.

Copyright 2018 BMJ Publishing Group. All rights reserved. For permission to reuse any of this content visit

https://www.bmj.com/company/products-services/rights-and-licensing/permissions/

BMJ Case Report Fellows may re-use this article for personal use and teaching without any further permission.

Become a Fellow of BMJ Case Reports today and you can:

- Submit as many cases as you like

- Enjoy fast sympathetic peer review and rapid publication of accepted articles

- Access all the published articles

Re-use any of the published material for personal use and teaching without further permission

For information on Institutional Fellowships contact consortiasales@bmjgroup.com

Visit casereports.bmj.com for more articles like this and to become a Fellow 